\title{
Under Scrutiny: The ECA, the ILO and the NZCTU Complaint 1993-1995
}

\author{
Nigel Haworth and Stephen Hughes*
}

In November 1994, the Governing body of the International Labour Organisation (the ILO) received the 295th Report of its Committee on Freedom of Association. Among the reports on complaints against the governments of Cameroon, Myanmar, Guatemala and others were the recommendations drawn from the Final Report on the February 1993 New Zealand Council of Trade Unions (the NZCTU) complaint against the government of New Zealand. The complaint, its processing and the Final Report have attracted great interest not only in New Zealand, but also on the international stage, where the substance of the complaint and the manner of its receipt by the New Zealand government has created widespread debate. Furthermore, the legislation against which the complaint was lodged the Employment Contracts Act 1991 (the ECA) - is itself of great international interest because of the ECA's commitment to a comprehensive free market model of bargaining. The progress of the NZCTU complaint through the ILO system raises a wide range of issues. Here we wish to discuss the extent to which the outcome of the complaint - in particular, the Final Report - responded to government, employer and union submissions and, consequently, the extent to which the ILO gave support to the contentions of the parties. In doing so, certain issues are raised, first, about the future of New Zealand-ILO relations and, second, about the expectations the parties should have about the ILO and its deliberations.

\section{NZCTU complaint to the ILO: a brief chronology}

The chronology of the NZCTU complaint begins with the enactment of the ECA in 1991. The status of this legislation vis-a-vis ILO principles was immediately an issue. The historical commitment by all parties in New Zealand to the ILO suggested that concerns felt by trade union bodies about the ECA might well find an outlet at the ILO in due course. When lodged with the ILO on 9 February 1993 the complaint centred upon the argument that the ECA violated two principle Conventions in the International Labour Code, Convention 87 Freedom of Association and the Protection of the Right to Organise, and Convention 98 Right to Organise and Collective Bargaining. New Zealand has never ratified either Convention (a fact constantly returned to by government and employer interests during, and after, the passage of the complaint). However, they are considered two

* University of Auckland. The authors acknowledge the support of the Auckland University Research Committee in the undertaking of this research. 


\section{Haworth and Hughes}

of the six basic human rights Conventions in the International Labour Code ${ }^{1}$ and as such are considered to have status above Conventions so that, "Such complaints may be presented whether or not the country concerned has ratified the freedom of association Conventions" (Final Report, 1994, para. 240)2.

Having received further submissions from the NZCTU in March and June of 1993, and the responses of the New Zealand government in September and October of that year, the complaint was first addressed at the November 1993 meeting of the Committee on Freedom of Association (CFA) where a full consideration of the complaint was postponed to March 1994. A mitigating factor in this decision was the "leak" of a CFA Tentative Working Paper on the case to the New Zealand press just prior to the 1993 General Election. Importantly the CFA refused to accept any more submissions on the complaint after its initial November 1993 deadline. It was a decision which would later colour the responses of government and employers in New Zealand.

As a result of the November 1993 decision the complaint was examined at the March 1994 meeting of the ILO Governing Body. The interim conclusions the CFA presented drew substantially on the conclusions of the earlier Tentative Working Paper and were accepted by the Governing Body and released as an official Interim Report. Of the 15 recommendations presented, the sum of which upheld the complaint, the final recommendation (not found in the Working Paper) proved to be particularly significant. Given the "enormous complexity" of the case, it was proposed, and officially accepted by the New Zealand government in April 1994, that a Direct Contacts Mission be undertaken to New Zealand. This took place in late September of that year. The Mission contributed to two reports - that of the Mission leader, produced as an appendix to the Final Report, and the Final Report, which consisted of a reworking and expansion of the Interim Report in the light of consideration of the mission's findings and further examination of the parties' submissions. The Final Report was accepted by the Governing Body in November 1994, when it was also released to the parties and the wider community.

\section{The Interim Report}

As noted, the process that ultimately put the New Zealand industrial relations system and the ECA under international scrutiny began with the filing of the NZCTU complaint with the ILO.

I The others being, the prohibition of forced labour (Conventions 29 and 105) and non-discrimination in employment (Conventions 100 and 111) (ILO Committee on Legal Issues and International Labour Standards, 1995). With the exception of 87 and 98 New Zealand has ratified all the human rights Conventions.

2 Why New Zealand has failed to ratify 87 and 98 owes much to its legislative history in the field of industrial relations; (see Anderson, 1986; Anderson and Brosnan, 1984). 


\section{The NZCTU complaint}

The elements of the NZCTU case against the ECA, as presented to the ILO in 1993, are reducible to nine points:

(a) In general, the ECA does not promote collective bargaining, as laid down in Article 4 of Convention 98.

(b) The consultation process associated with the select committee proceedings was inadequate, in that the bill was not in substance amended despite a preponderance of submissions critical of the bill. This was presented as a rejection of tripartite principles at the heart of ILO tradition.

(c) The extent of collective bargaining has been substantially reduced by the operation of the ECA, contradicting ILO principles.

(d) Collective bargaining as a process is undermined by the possibility of collective contracts emerging without collective bargaining or the participation of workers' organisations.

(e) The possibility of "good faith" bargaining has been eroded by employer interference in worker organisations and discrimination against legitimately established workers' organisations.

(f) The effects of (e) above include violations of Articles 3, 8 and 11 of Conventions 87 , in that union rights may now be excluded from or limited in collective contracts.

(g) The level at which bargaining may take place has been effectively fixed as the enterprise, denying the parties the right to seek bargaining opportunities at multienterprise, industry and national levels.

(h) The government has, via its State Wage Fixing Committee and the State Services Commission, interfered in the bargaining process in order to predetermine bargaining outcomes, thus substantially constraining bargaining freedoms.

(i) The right to strike has been limited to two contexts: the search for a new collective agreement when an existing agreement has expired, and in extreme health and safety situations.

These arguments were supported by a range of examples drawn from early experiences under the ECA. They reflected a set of beliefs about the ECA which had gained widespread support amongst unions and employees in general, and also some analytical support from labour law specialists (see for example, Hughes, J., 1992; Kiely and Caisley, 1993). Equally, however, neither government nor employer organisations agreed with the interpretation of outcomes of the ECA provided by the NZCTU. 


\section{The New Zealand government response}

Government replied to the NZCTU's complaint in the following terms:

(a) The ECA is the logical and necessary culmination of a general process of deregulation in New Zealand post-1984, and a specific reform process in labour relations begun in 1985 (and with origins in 1973).

(b) The ECA is precisely based on concepts of voluntary association and freedom of association and, consequently, is true to ILO principles in this regard.

(c) Within the need for change, collective bargaining continues to be an available mechanism for fixing employer-employee relations and unions may play as an extensive role in this process as voluntary membership permits.

(d) The reduction in the extent of collective bargaining is in part due to the operation of freedom of choice by both employees and employers in the bargaining situation, and in part to the adjustment process associated with the introduction of the ECA.

(e) The select committee process is not seen as a referendum and the balance of commentary in the submissions made is not germane.

(f) The reduction in the coverage of collective agreements is the consequence of the end of the "subsequent parties" model coupled to a secular trend towards enterprise bargaining in New Zealand. The figures in the NZCTU complaint in relation to collective coverage are subject to revision and reinterpretation such that the dramatic impact of the ECA on collective coverage claimed by the NZCTU is exaggerated.

(g) Unions continue to play a leading role in collective bargaining under the ECA, in the context where individual responsibility for bargaining is promoted by means of the choices made available to the individual under the ECA.

(h) The pattern of interference and discrimination in bargaining by employees described by the NZCTU is at odds with the case law relating to the ECA and with the protections laid out in the ECA.

(i) Good faith bargaining is not an issue as the Employment Court has rejected the claim that good faith bargaining may be derived from New Zealand law.

(j) Interference by government in bargaining outcomes or in the establishment of bargaining levels is denied by government. Rather, in the cases raised by the NZCTU, either the SSC or the Cabinet Subcommittee on State Wages has simply been advised of possible bargaining outcomes. There is no attempt to direct bargaining outcomes by government. Government seeks to establish strategies for bargaining in the State sector, rather than to fix outcomes. 
(k) Strikes are permitted in the search for a new collective agreement. They are not permitted in furtherance of demands for multi-firm bargaining as this imposes an unacceptable constraint on employer freedom of choice. Strikes not directly related to specific industrial issues are not prohibited in New Zealand law, but are not protected against legal proceedings. This balance is acceptable to government.

\section{Conclusions of the Interim Report}

The CFA drew together both sides of the complaint and produced a series of conclusions in its Interim Report. Balancing the various arguments against each other, the Committee argued:

(a) The ECA does not encourage and promote collective bargaining as it places greatest emphasis on individual responsibility in bargaining to the detriment of collective agreements.

(b) Protection against interference and discrimination on the basis of membership of a union is insufficient in New Zealand, particularly in relation to employer undermining of negotiation authorisation and possible interference by employers in the internal affairs of employee organisations.

(c) The ECA may permit employer-dominated or appointed representatives to bargain for employees, in breach of ILO principles relating to the independence of bargaining parties.

(d) The authorisation procedures under the ECA may impede workers' abilities to organise.

(e) The ECA is broadly tolerant of access rights to workplaces for union organisations

(f) The ECA improperly impedes worker actions to seek to bargain at levels above enterprise bargaining.

(g) The government is exonerated of accusations that it improperly intervenes into negotiations on the basis of the cases presented.

(h) The ECA's narrow definition of what constitutes a lawful strike appears to deny to unions the recourse to protest strikes in relation to a government's economic or social policies, a limitation at odds with ILO principles.

The full weight of the CFA's deliberation was focused in the 15 recommendations which flowed from the analysis of the NZCTU and government cases. Given the tenor of these recommendations, and notwithstanding the rejection of the elements of the complaint relating to, for example, access to the workplace for union representatives and improper government interference in bargaining, the NZCTU believed that the complaint had been substantially upheld by the CFA's Interim Report. Taken as a whole, the recommendations 
implied that the ECA is generally at odds with both freedom of association and collective bargaining principles of the ILO.

The full significance of the recommendations was perhaps best captured by the final recommendation which asked the New Zealand government to accept a Direct Contacts Mission, intended to make a definitive examination of the issues raised by the complaint. In both government and employer circles in New Zealand, feelings about the complaint and the ILO's response ran high. The status of the ECA as icon in the New Zealand reform process guaranteed that measured criticism, even by a body as respectable and conservative as the ILO, would give rise to a strongly defensive reaction. Consequently, in the media and in popular debate, the status of the recommendations and of the Mission became a topic of heated, often quite uninformed, discussion ${ }^{3}$.

\section{The Final Report}

The Final Report, released in November 1994, was based on three sources. First, the Interim Report; second, the report of the Direct Contacts Mission and, third, a range of further submissions made by the parties subsequent to the release of the Interim Report.

\section{Submissions to the Final Report: The Direct Contacts Mission}

The Direct Contacts Mission visited New Zealand from the 19th to the 27th of September 1994. It consisted of two people, both labour lawyers, one contracted to the ILO after many years of international labour law experience, the other a senior ILO official. Over a period of eight days, the Mission met a wide range of representatives from the parties, plus a group of commentators with specific knowledge about the operation of the ECA.

In the Mission's report, the role of the ECA in the overall strategy of government was the first area of note covered. The divisions between the parties, and between political tradition, over the ECA were traced, and the status of the ECA as a key factor providing flexibility for economic growth was explored. However, the CFA's Final Report made it quite clear that such considerations were not relevant to the exploration of the factors pertinent to the complaint. It argued that "it (CFA) is not called in this case to examine whether and to what extent the Act has contributed to an improvement in the fiscal, financial and economic situation of the country" (Final Report para. 237). The CFA was also moved to suggest that statistics and analysis of causal relationships, for example between a piece of labour relations legislation and economic performance, are open to myriad differing interpretations, and simply were not the concern of the ILO investigation process (Ibid). Equally, the efficiency or not of one bargaining system or another for the

3 Even after the departure of the Mission and the release of the Final Report some potentially influential contributions to this discussion revealed a surprising lack in understanding of the issues. See for example the editorial response of the NZ Herald 17 February 1995 to the discussion paper on the complaint released by Haworth and Hughes. 
achievement of flexibility was not of interest to the investigation of the complaint (Final Report para. 238).

The Mission Report laid out the main features of the ECA, noting that the outcomes possible under a structure that permits both collective and individual bargaining, or a combination of the two, open up great complexities. It also noted the problems associated with the data available on the operation of the ECA, in part the direct consequence of the legislation which requires the Department of Labour to gather only partial data, and in part due to conflicting bases used across such surveys as exist. The Mission made the important point that there were limitations to the contribution the various data could make as far as the CFA's consideration of the complaint was concerned (Mission Report para. 39). It also presented caveats relating to the relevance of judicial decisions to the ECA. Of note were the weight to be attached to judicial decisions such as those in the Capital Coast Health or Eketone cases in the future operation of the ECA, the desirability or not of judicial decisions acting to define the ECA (rather than the ECA itself providing greater explicit guidance on expected outcomes), and the extent to which cases used to illustrate the ECA were accurate in detail and reflected the bargaining culture in New Zealand. Implicit in these comments was the difficulty facing such a Mission, when confronted by complex legislation, its judicial interpretation, and its presentation by partial parties.

The substantive sections of the Mission Report covered a range of areas: consultation, employee representation, recognition issues, the promotion of collective bargaining, multiemployer bargaining, and the strikes issue. The Mission made little headway in the area of consultation and the operation of the select committee process in the introduction of the bill, though the clear similarity of position underlining employer and government agreement on this matter was recognised (Mission Report para. 52).

In the authorisation area, the Mission recognised that, whilst the ECA does not specifically provide protection against interference by employers in the employee's designation of a bargaining agent, judicial decisions have partially closed the gap. Thus in its discussion of employee representation, and in particular when looking at the NZCTU charge that bargaining under the ECA was taking place on the basis of agents imposed by or dominated by employers, the Mission placed the weight of its observations on the government and NZEF contention that protections under the ECA minimise this effect, and that the Capital Coast Health decision provides evidence of this protection. However the Mission was moved to note the continuing NZCTU scepticism on this count (Mission Report, para. 69).

On workplace access rights for bargaining agents, the Mission took no position on the NZCTU belief that access for recruitment purposes should be allowed under the ECA. The mission noted that access to already recruited members of unions had been reinforced by the Employment Court in the Southern Pacific Hotels and Foodstuffs (Auckland) Ltd cases. On the issue of employer demands for proof of authority to represent a group of employees, the Mission suggested that, apart from some confusion about what is at issue in this area, there exists a continuing gulf between the NZCTU position that the ECA allows employers to obstruct bargaining by means of bureaucratic procedures, and the government's position that some element of this is necessary in order to safeguard the individual's choice of representation. 
The Mission addressed the recognition and requirement to bargain issues raised in the NZCTU complaint in terms of the impact of the Court of Appeal's decision in the Eketone case, as consolidated in the Capital Coast Health decision. Despite noting the continuing concerns of the NZCTU that these decisions do not provide certain protection, the Mission appeared to place weight on the judicial view that, once a bargaining agent has established authorisations from a group of workers, the requirement to recognise the bargaining agent carries with it both the commitment to bargain with that agent and to refrain from attempts to negotiate independently and individually with the workers.

In its section on the encouragement and protection of collective bargaining, discussion turned on the intentions behind the ECA. Is the ECA, as Max Bradford, chairperson of the parliamentary select committee that stewarded the legislation, asserts, neutral as between individual and collective bargaining, or is it intended to promote the former at the expense of the latter? The employer comments to the Mission, which supported both a shift from collective to individual bargaining and the underpinning philosophical traditions of the ECA, argued for the ECA to be seen as promoting fragmented, individualised bargaining within a framework of freedom of choice for the individual.

Finally, on the issue of strikes the evidence gathered by the Mission simply reinforced the unity of perception binding together employer parties and government in support of the ECA and against the NZCTU complaint. Central to this unity is the concern that strike action in support, for example, of multi-enterprise bargaining, would contradict the freedom of choice available to employers in terms of a preferred level of bargaining. As the third recommendation of the Final Report asserts, this position expressly offends ILO principles.

\section{Submissions to the Final Report: The NZCTU}

The material gathered by the Mission and presented in its report was combined with further materials presented to the CFA by the parties in response to the contents of the Interim Report. Summarising its further evidence to the CFA, the NZCTU argued:

(a) There is under the ECA no explicit process of recognition of workers' organisations, and the effect of the ECA is to compound this by undermining collective bargaining in that the collective outcomes possible under the act are simply the product of bargaining on behalf of individuals, rather than the product of collective bargaining as understood by the ILO.

(b) Whilst "by passing" of authorised bargaining agents by employers has been constrained by judicial decisions, only extreme cases of interference with representation have been addressed. Also, the use of court orders to require employers to recognise an authorised agent is long and costly and, in any case, in practice the effect of the ECA is to allow employers to continue to "bypass" authorised agents. 
(c) The statistical data and the compendium effects of the ECA have the incontrovertible effect of reducing the extent of collective bargaining, thus clearly not encouraging and promoting collective bargaining.

(d) Employer pressure on employees to withdraw authorisation for a union continues to be legal under the ECA, up to the point, as yet undefined, when such pressure becomes "undue". The courts may rule on this, but litigation is costly in time and financial terms.

(e) Protection in relation to interference with and discrimination against members of unions continues to be inadequate, particularly given that unions receive no recognition or definition of role under the law.

(f) Employers may still set up and fund worker organisations, and employer-dominated representation is quite possible. This contradicts fundamental ILO principles.

(g) The definition of essential industries in which strike action is legally constrained in New Zealand is particularly wide and carries with it a range of logistical impediments to organised worker action.

(h) The NZCTU suggests that the ILO should look closely at the areas of employment in New Zealand where union activity and collective bargaining have fallen away badly in order to understand the effects of the ECA. In relation to this, the predominance of firms of small size in the New Zealand economy exacerbates the impact of the ECA on collective bargaining and the creation of independent worker organisations.

The NZCTU supported this additional material with eleven cases illustrating their perceptions of the operation of the ECA (Final Report para. 154, pp. 47-50).

\section{Submissions to the Final Report: The New Zealand government}

The government responded to the Interim Report by again locating the ECA in the context of a policy for growth and international competitiveness, and by offering specific rebuttals of the interim conclusions of the CFA. The general arguments covered macro economic performance data, the role of the ECA in the achievement of these results, the legal protections provided by the rule of law in New Zealand, and the particular framework governing employment law.

The government then moved to the interim recommendations of the CFA. This commentary may be summarised as follows:

(a) The channels for consultation about legislation in New Zealand are broad and effective, and are as fully developed as one might expect in a mature democracy. Therefore any complaint about the enactment of the ECA is spurious. 
(b) Trade unions are recognised in New Zealand law and receive some legal protection in the 1908 Trade Unions Act. The status of unions as authorised bargaining agents is further recognised by judicial decisions such as that in the Capital Coast Health case. This case, in conjunction with others, has also provided clear guidelines on the requirements to recognise and bargain with authorised representatives. Access to meet authorising workers is now clearly guaranteed in law (ECA, section 14) and by judicial decision (the Southern Pacific Hotels case).

(c) The ECA encourages collective bargaining in that it makes explicit and wide-ranging provision for collective contracts. These provisions have been firmly set in place by a range of judicial decisions.

(d) Not only is collective bargaining promoted by the ECA, but also, for the first time, the ECA provides the possibility of collective bargaining for all New Zealand employees, a possibility previously only available to employees covered by a registered union operating within the old award framework.

(e) Statistical evidence shows that, for example, 61 percent of employees covered by contracts negotiated under the ECA are covered by collectively negotiated contracts. Not only is the statistical evidence of collective bargaining supportive of the government case, but so too is other evidence suggesting that the process of change under the ECA is stabilising.

(f) The Capital Coast Health and Eketone cases respectively provide judicial constraint against employer pressure to withdraw bargaining agent authorisation, and against employer interference with and discrimination against authorised representatives.

(g) Survey material suggests that representation by unions is increasing (contrary to the complainant's view that unions face discrimination and interference) and that the vast majority of employees feel free to choose their representatives and are happy with their representation. The government, in passing, suggested that the cases used by the NZCTU to show the contrary are in fact anecdotal and do not hold up under detailed, objective scrutiny.

(h) The need to establish authority to represent does not, in the government view, constitute an impediment to the right of workers' organisations to represent their members. Any attempt to use this avenue by employers would be subject to judicial constraint in terms of the Employment Court's emphasis on a mutual obligations of trust and confidence, as enunciated in the Capital Coast Health case.

(i) In relation to multi-employer contracts, the government pointed out that this continues to be an option chosen by some employers and, indeed, may be increasing in incidence. However, the freedom of choice for employers in bargaining outcomes must be respected and protection must be provided for the employer facing disruption caused by employees outwith the firm over whom they have no control and in providing protection from being bound by collective agreements that involve potential competitors. Hence, the provisions vis-a-vis multi-employer strikes should be maintained. The government reasserted, too, that strikes on social and economic 
issues are not deemed to be unlawful in New Zealand, but equally they are not specifically protected in law. The government's view was that this was appropriate.

Appended to this set of government responses to the Interim Report was a further document providing a case-by-case rebuttal of NZCTU charges relating to individual cases (Final Report paras. 199-234, pp. 67-78). This document offered the detailed account of the development of bargaining practice and judicial decisions under the ECA which supported the broad contentions of the government.

\section{Presenting the Final Report: differences between the ILO and government}

Government, employer and media commentary in New Zealand presented the Final Report as an exoneration of the ECA from the charges laid in the NZCTU complaint, and regarded the reduction of recommendations from fifteen in the Interim Report to four in the Final Report as evidence of informed analysis of the ECA, rather than the expression of dubious prejudice. Furthermore, the seemingly bland nature of the recommendations was interpreted in New Zealand as a pro forma outcome to a concluded procedure. As far as popular commentary was concerned, the NZCTU complaint was dismissed. Not surprisingly, the NZCTU took a different view in its public statements, noting that the four recommendations were not the sum of the parts of the Final Report and suggesting that the recommendations made in the report were of greater moment than their simple number would suggest.

It is clear from our research that the NZCTU position on the Final Report is in accord with the views held in the ILO. It is widely accepted in ILO circles in Geneva that the public interpretation of the Final Report offered by the New Zealand government is seriously at odds with the report's contents and intentions. The grounds for concern at the New Zealand government's statements essentially lie in two areas and to these we now turn.

\section{Examining the Final Report}

The first broad area of concern relates to the status of the Final Report's recommendations, vis-a-vis the body of the report. In the ILO view, the recommendations must be read in the light of the report as a whole and should not be seen as the comprehensive judgment of the CFA. More precisely, for example, the recommendations must be understood in the context of paragraphs 254 and 255 of the report. To quote:

Paragraph 254. On the whole, taking into account the provisions of the Act and the information contained in the mission report, the Committee considers that problems of incompatibility between ILO principles on collective bargaining and the Act stem in large part from the latter's underlying philosophy, which puts on the same footing (a) individual and collective employment contracts, and (b) individual and collective representation.

Paragraph 255. As regards employment contracts, the Committee finds it difficult to reconcile the equal status given in the Act to individual and 
collective contracts with the ILO principles on collective bargaining according to which the full development and utilisation of machinery for voluntary negotiation between employers or employers' organisations and workers organisations should be encouraged and promoted, with a view to the regulation of terms and conditions of employment by means of collective agreements. In effect, it seems that the Act allows collective bargaining by means of collective agreements, along with other alternatives, rather than promoting and encouraging it. The Committee, therefore, hereunder draws the attention of the government to certain principles it has established in this respect." (Final Report, p.84).

As is obvious from these paragraphs, the ILO continues to entertain grave concerns about the operation of the ECA on two counts. First, the status of individual bargaining given by the ECA is in direct contradiction to ILO principles of collective bargaining and, by extension, to the parallel principles of tripartism. In the discourse of the ILO, this criticism remains a fundamental issue putting the ECA at odds with ILO practice. In a host of contexts, not only that of Convention 98, the ILO has established precedence for collective bargaining in labour relations and the ECA contradicts this precedence.

In examining the concerns raised by the different interpretations of the Final Report it is useful here to reflect on the early debate about the ECA during its passage through parliament. One issue which attracted attention was the issue of the relative weight attached to individual and collective bargaining by the ECA. Whilst this issue was in part obscured by the rhetoric associated with freedom of choice in bargaining regimes for the parties, the practical consequence of the ECA in terms of which alternative had priority was widely debated. In philosophical terms, and notwithstanding the "freedom to choose" argument, the ECA has been widely seen as a measure establishing the priority of individual outcomes over collective outcomes. In practice, this is seen not only in the much reduced incidence of collective bargaining in New Zealand, but also in the freedoms given to employers to bypass collective outcomes. It is the case, of course, that judicial decisions in, for example, Capital Coast Health have provided interpretation of this employer freedom somewhat at odds with the intention of the ECA, but it remains the case that such judicial decisions constitute a perversion of the ECA in the eyes of many of its supporters.

Supporters of the ECA turn their attention not to the alignment of the ECA with ILO principles but to the demand that the Employment Court and all specialist labour jurisdictions be abolished. This notwithstanding, the ECA was designed to create a paramount status for the individual over the collective and, as such, offends ILO principles. Further, the principles of the ILO are not couched in terms of the permission of collective bargaining. In the ECA, collective bargaining is a permitted outcome, albeit not the outcome most explicitly promoted. Adherence to ILO principles requires the promotion and encouragement of collective bargaining as a desirable outcome for all parties. The ECA clearly does not encourage collective bargaining and, consequently, offends ILO principles.

In a sense, this combination of criticisms, not made explicit in the Final Report's four recommendations, establishes the grounds for a continued ILO concern about labour relations provisions in New Zealand. The report is in effect saying in quite stark terms that the ECA offends the fundamental bargaining rationale established by the tripartite ILO 
process. From this follows a range of related concerns, again not explicitly confronted in the recommendations. For example, despite judicial interpretations relating to requirements to bargain with authorised bargaining agents, the CFA is clearly still disturbed about the intention of the ECA to allow employer's to refuse to negotiate with authorised agents (Final Report, paras. 247-246). Similarly, important unresolved issues exist about the failure of the ECA to require bargaining in good faith (Final Report, para. 257).

\section{The four recommendations}

The second broad area of concern raised in the ILO by the government's public interpretation of the Final Report centres on the interpretation of the four recommendations. The first recommendation requests the New Zealand government to keep the ILO informed of judicial proceedings with implications for the ECA. As paragraph 250 indicates, the CFA accepts that new legislation and its subsequent case-law require time to bed in. Paragraph 248 accepts that the intention of the ECA may be subject to adjustment in line with ILO principles as a result of judicial decisions, but paragraphs 249 and 251 also make it clear that the CFA is not comfortable with a gradual process of accommodation of the ECA with ILO principles by means of cumulative case-law. Hence, the CFA clearly intends to monitor case-law developments in regard to the ECA on an ongoing basis, and, consequently, expects the ECA to be on future ILO agendas, perhaps even on a regular basis. This is but one indication that, despite the impression given by the New Zealand government, the ECA is not a concluded issue at the ILO.

The second recommendation, mildly worded on first reading, is an explicit statement of the CFA's view that the ECA is at odds with ILO collective bargaining principles. It further suggests that the ECA requires amendment to bring it into line with ILO principles and that the expected mechanism for this to be achieved is tripartite discussion. Progress in this area is to be notified to the CFA. Behind the mild formulation adopted lies a quite explicit statement of criticism of the ECA and an equally explicit expectation that the New Zealand government will take steps to revise the ECA on the basis of tripartism. Thus not only is the issue of the ECA not resolved but also the ILO expects changes to occur and be notified to its Governing Body. Parties are in a position, as a result of this recommendation, to raise the issue of the ECA on an ongoing basis within the ILO and the New Zealand government will be expected to respond effectively to these ongoing queries.

The third recommendation, dealing with the particular issue of industrial action in support of multi-employer collective agreements, is clear-cut and at odds with the New Zealand government's expressed policy. The ILO has not accepted the New Zealand government's position on this issue (Final Report, para. 259) and is in effect calling for a major amendment of section 63 of the ECA. Equally the government has stated that no such amendment will be forthcoming. Once again, we can expect the CFA to return to this specific issue in its future discussions.

Finally, the fourth recommendation essentially reminds the parties in New Zealand that the ILO is able to make available a wide range of technical and advisory services to New Zealand if such services are helpful. There are, it appears, two issues underpinning this 
offer of support. The first is the obvious interpretation that the creation of an effective tripartite dialogue in a context where legislation has hastened the erosion of traditional interparty involvement might well be helped by external advisory support. Second the recommendation responds to a view expressed in the Direct Contact Mission's report (para. 115 ) which indicates a willingness or a readiness on the part of all three parties to engage in constructive discussion around legislative charge which might overcome the problems giving rise to the initial complaint.

From the perspective of New Zealand commentators, the presence of such a consensus for discussion and possible amendment of the ECA is difficult is identify. Indeed, the arguments presented to the ILO by New Zealand government in relation to both the initial complaint and the visit by the Mission placed the ECA at the heart of its economic strategy in a manner which brooked no pressure for reform. When considering the sometimes intemperate comments made by various commentators about the role of the ILO in the complaint process, and about the ILO in general, one sees even less possibility of tripartite revision of the ECA with a technical input from the ILO. Yet, for all the commitment to the ECA shared by government and many employers, the direction of judicial decisions, when coupled to the critique of the ECA made in the Final Report, does suggest that grounds exist for a review of some key sections of the ECA. The willingness of the two largest opposition political parties to consider such a review adds weight to the pressure created as a result of the ILO complaints process.

\section{The tripartite parties and the ILO}

The three parties involved in the ILO discussion of the NZCTU complaint reacted to the outcome in predictable fashions. The government position moved from intemperate criticism of the ILO in response to the Interim Report to a more measured response following the release of the Final Report. Government has portrayed the Final Report as an exoneration of the ECA from the complaint and, consequently, sees the matter as closed. The NZCTU takes a different view based on a reading of the whole of the Final Report. Hence, NZCTU commentaries stress the continuing differences between the ECA and ILO principles and the consequent need for amendment of the ECA. The Employers Federation has adopted a line similar to that of government.

The development of these responses to the Final Report warrants extended discussion, for it captures not only the parties' relationships with the ILO but also the issue of expectations held about membership of the ILO. The New Zealand government is a long-term supporter of the ILO. Indeed, Walter Nash was the President of the ILO body which set in place its post World War II mandate - the Declaration of Philadelphia 1944. And current New Zealand Prime Minister Jim Bolger was President of the 69th International Labour Conference in 1983. However, in recent years, there has been some friction between the ILO and successive New Zealand governments.

In the latter half of the 1980s, both Labour Ministers Stan Rodger and Helen Clark found themselves at odds with the ILO. In June 1989, Rodger called for a fundamental review of the ILO and its activities, arguing that "nothing, save the central tenet of the organisation 
peace through social justice through humane conditions of work - should be sacred in such an exercise" ${ }^{14}$. In May 1990, Helen Clark, responding to an ILO finding in favour of a New Zealand Employers Federation complaint against the 1987 Labour Relations Act, commented that the government had "no immediate intention of changing its position in relation to either the registration system or the 1000 membership requirement" ${ }^{5}$. Given that these comments were made by Labour government ministers from a tradition strongly supportive of the ILO, tripartism and international labour standards, it is clear that differences between New Zealand and the ILO are not the sole province of National governments.

\section{Government responses}

The government's public responses to the Interim Report were at best forceful, at worst lamentable. They appeared to reflect two central beliefs; first, that the centrality of the ECA to New Zealand's economic model brooked no international scrutiny of the legislation; second, that the ILO was a redundant institution. As we have argued elsewhere, such a response begs the question of New Zealand's continuing membership of the ILO (Haworth and Hughes, 1995). These responses to the Interim Report are in contrast with responses to the Final Report. Arguing that the ECA had been exonerated by the report, the government took the line in parliament that New Zealand intended to stay in the ILO and work for its reform. This shift in the tenor of government commentary is not simply a function of interpretation (however incorrect) of the Final Report. It captures a discussion in Wellington and Geneva between the Minister of Labour, the Minister of Foreign Affairs and Trade and their respective departments. Advice received from his department by the Minister of Labour was placatory in tone, stressing the positive aspects of the Final Report, downplaying the continuing differences between ILO principles and the ECA, and implicitly supporting a commitment to the ILO. Interestingly, the anodyne statement made in Geneva to the ILO's Governing Body following the publication of the Final Report was drafted by the Ministry of Foreign Affairs and Trade, rather than the Department of Labour.

There is here a strong sense of the senior department moving into an international issue to defuse tensions. This is understandable. New Zealand has in recent years sought to play a more significant role on the international stage. The successful lobbying for a UN Security Council seat was the most obvious example of this desire. This thrust is not helped by the New Zealand government appearing to dismiss summarily a major international agency, which is also an important forum within the United Nations (the UN) system. An interesting dimension of ILO-government relations during the passage of the NZCTU complaint through the ILO committee structure was the lobbying carried out by New Zealand diplomats in order to influence key member nations of the CFA. We can infer from this that, despite the tenor of government's responses to the Interim Report, the need to act on the diplomatic front promptly in order to seek a revision of the report's recommendations

4 The ILO: Time for Reform. Address to ILO Conference, Geneva, June 1989. A similar message was delivered by Stan Rodger as Government delegate to the International Labour Conference of 1990.

5 Letter to the ILO dated 24 May 1990. 
was recognised. Whilst we know from our research that this lobbying took place and that its immediate aim was to create support for revised or withdrawn recommendations, the existence of a wider agenda relating to the reform of the ILO is still to be ascertained.

The New Zealand government must also see the issue of the ILO against the background of domestic politics. In the complex arena of party realignments under MMP, domestic issues - education, health, employment, superannuation - combine with negotiations about future party alliances to displace international issues in the minds of many politicians. This domestic focus, attached to the truculence shown in government statements relating to the ECA, is a compelling framework for understanding government responses to the NZCTU complaint.

\section{Employer responses}

The response of the New Zealand Employers Federation (the NZEF) to the complaint was predictable, given the organisation's forthright commitment to the ECA. The NZEF also responded to the Interim Report in extreme fashion, echoing government questioning about the status and future of the ILO. In contrast to its public voice, written submissions by the NZEF to the CFA during the course of the complaint were more sober in analysis and repeated the government's response of "constructive engagement" with the ILO.

Arguably, the ILO means less to the employers' group than it does to government or the NZCTU. For government, the ILO is a major international institution with important diplomatic connotations. For the NZCTU, the ILO is a major agency supporting improved employment conditions. For New Zealand employers, concerned in recent years to reduce external intervention into the enterprise, and perhaps no longer wedded firmly to tripartism or collective bargaining, the ILO is an anachronism. Yet, the NZEF participates actively in ILO councils and makes good use of the employer networks which the ILO fosters. Moreover, the ILO also offers an international stage upon which New Zealand employers' representatives can appear.

\section{Union responses}

The NZCTU, as initiator of the complaint, stood to win or lose most. The complaint was an attempt to focus international opprobrium on legislation which offended ILO principles. It was, therefore, not only seeking to focus the ILO's technical lens on the ECA, but also to bring diplomatic pressure to bear on New Zealand. The Interim Report, and its reception in Geneva and New Zealand, gave the NZCTU reason to be happy. Whilst not receiving support for all its claims, the NZCTU saw in the Interim Report consistent justification for the complaint. Similarly, the Final Report was well received by the NZCTU. Rejecting the government's interpretation of the four recommendations and preferring to base its comments on a full reading of the report, the NZCTU felt that the complaint was firmly upheld by the ILO. Procedurally, the NZCTU feels that its use of the ILO has been fully warranted. 
The NZCTU supports the ILO as the paramount international agency concerned with labour standards and their maintenance. The ILO's commitment to tripartism, union recognition and collective bargaining, and the overarching commitment to social justice combine to give the ILO a particular status in the eyes of union organisations such as the NZCTU. That said, the ILO acts in terms of its conventions and procedures, not in terms of the parties' predilections. In both reports relating to the NZCTU complaint, key NZCTU arguments against the ECA were rejected by the CFA. Evidence of breaches of ILO conventions put forward by the NZCTU was in some cases explicitly rejected. Furthermore, the procedural precision of ILO investigations has "disallowed" certain arguments put forward by the NZCTU and its supporters in association with the complaint. For example, the Direct Contact Mission was unwilling to accept evidence offered of impacts of the ECA on "secondary" labour markets. The staff of the Mission preferred to conduct a precise investigation of the complaint in terms of possible breaches of conventions rather than in terms of more general issues. Similarly, the government's situation of the ECA in the broad context of deregulation and restructuring was rejected by the Mission and in the Final Report as irrelevant to the investigation of the complaint. For any party, therefore, a complaint to the ILO requires adherence to the procedural traditions of the organisation.

\section{Conclusion}

Permeating the parties' involvement in the complaint process were mixed signals about the powers of the ILO and its ability to intervene in national practices. For example, the constitutional right to process the complaint does not in any way establish a requirement on the part of any party to amend an industrial relations practice subject to criticism. Thus, the New Zealand government, like its predecessor, need not respond to the criticisms contained in the Final Report. It may choose to respond, if technical or moral arguments so move it, but the position adopted by the ILO is essentially advisory. Thus, for both government and employers' bodies, there need not be any qualification of the operation of the ECA following the publication of the Final Report.

The rationale for this is two fold. First, the ILO is, despite its size, history and status as a UN agency, a voluntary body. Nations and their associated parties choose to belong. Equally, they may choose not to belong, or to relinquish an existing membership. The only power available to the ILO rests in the weight of its status which may be brought to bear as moral pressure on governments and parties. Second, the ILO's tripartite structure produces consensus outcomes between the parties. Such outcomes, particularly when consolidated into a Convention, tend to be the product of long-term consideration and negotiation. Whilst subject to revision, such outcomes will enjoy an extended life and are unlikely to be vicariously abandoned. Equally, however, their tripartite origins in a centralised, international institution are possible only because of the outcomes' advisory or exhortatory quality.

Tripartism and international status contribute to a further aspect of ILO deliberations - the formalistic approach to procedure. Because ILO procedures are subject to constant monitoring by the parties, there is strong tendency for ILO activities to be highly formal. This was true in the case of the NZCTU complaint when, for example, submissions relating 
to the impact of the ECA on the secondary labour market were deemed to be ultra vires in terms of the conventions under which the complaint was laid. The international role played by the ILO reinforces the formalism displayed by ILO officials. Their role is that of international civil servants, explicitly bound by professionalism to the interpretation of tripartite outcomes, rather than to self-determined agendas.

In these contexts, the NZCTU would be the party most likely to display impatience with the ILO as an institution. From the NZCTU perspective, the ILO has presented a strong critique of the ECA, and some explicit and implicit requirements for its amendment. Nevertheless, because of the ILO's voluntary nature, effective action is unlikely, particularly given the blandly diplomatic comment made to the ILO's Governing Body by the New Zealand government after the publication of the Final Report. Similarly, the NZCTU may well be aggrieved that important aspects of its case, such as the secondary labour market issue, have been excluded from consideration as a result of ILO formalism. However, we argue that such impatience would be surprising in the case of any party with ILO experience. To be involved in the ILO is to understand the voluntary nature of the ILO and the formal manner of ILO procedures. To harbour expectations beyond those permitted by the traditions of the ILO seems to us to be unrealistic. It is on these terms that we expect further scrutiny of the ECA in the future.

\section{References}

Anderson, Gordon and Peter Brosnan (1984), Freedom of Association: New Zealand Law and ILO Convention 87. New Zealand Law Journal, September, pp.307-310.

Anderson, Gordon (1986), International Labour Standards and the Review of Industrial Law New Zealand Journal of Industrial Relations, 11(1): 27-38.

Haworth, Nigel and Stephen Hughes (1995), New Zealand and the ILO: Current Debates and Future Directions Discussion Paper, Department of Management and Employment Relations, The University of Auckland, February.

Hughes, John (1992), The Employment Contracts Act one year on: institutions and grievance handling Industrial Relations Centre, Victoria University of Wellington, Working Paper 3/92.

ILO (1994), 292nd Report by the Committee on Freedom of Association to the 259th Session of the Governing Body of the ILO, Case no. 1698, Complaint against the Government of New Zealand by the New Zealand Council of Trade Unions. Geneva, March.

ILO (1994), 295th Report by the Committee on Freedom of Association to the 261 st Session of the Governing Body of the ILO, Case no. 1698, Complaint against the Government of New Zealand by the New Zealand Council of Trade Unions. Geneva, November. 
ILO (1995), Report of the Committee on Legal Issues and International Labour Standards to the 262nd Session of the Governing Body of the ILO. March-April.

Kiely, Peter and Andrew Caisley (1993), The legal status of bargaining under the Employment Contracts Act 1991: a review of recent cases, in Harbridge, Raymond (Ed.) Employment Contracts: New Zealand Experiences Wellington: Victoria University Press.

\section{Cases Referenced}

Eketone and Docherty v Alliance Textiles and others (CA 388/91; Court of Appeal judgement given 5 November 1993).

National Distribution Union v Foodstuffs (Auckland) Ltd (AEC33/94; A26/93; A33/93; Employment Court judgement given 17 June 1994).

New Zealand Medical Laboratory Workers Union and others v Capital Coast Health Limited (WEC45/94; Employment Court judgement given 12 August 1994).

Service Workers Union v Southern Pacific Hotel Corporation and others (WEC27/93; W21/93; Employment Court judgement given 1 October 1993). 